\title{
Productive, Distributive, Dynamic, and Allocative Efficiency Improvement Model in Colombian Public Universities
}

\author{
Modelo de mejoramiento de la eficiencia Productiva, distributiva, de asignación y \\ dinámica en las universidades públicas de Colombia
}

\author{
W. Arenas-Valencia, iD ; J. J. Cabello-Eras id \\ DOI: https://doi.org/10.22517/23447214.24606 \\ Artículo de investigación científica y tecnológica
}

\begin{abstract}
The measurement of efficiency in public universities has been a topic of interest for researchers and state officials in Colombia; this article presents a model that transcends the view of productive efficiency, and expands it by including aspects of equity with distributive efficiency, of acceptance by society in the allocative efficiency, and finally with the dynamic efficiency includes the time variable, with which the state can measure the stability of the indicators of interest. For the design of the model, multivariate statistical techniques and non-parametric techniques were used, such as Structural Equation Models, Principal Component Analysis, Data Envelopment Analysis, and the Balanced Scorecard. Different ranks are obtained with which university improvement plans were identified, emphasizing public institutions with high quality accreditation. A Balanced Scorecard is proposed with the indicators extracted from the sector databases that met the conditions of the techniques used. This technique suggests a causal relationship between the indicators of distributive, productive, and allocative efficiencies, where the perspective of inclusion forms the basis of the scorecard, affecting the perspective of education and research and the latter influencing the perspective of impact. Finally, it is concluded that the public university sector has great challenges in terms of inclusion and measurement of the satisfaction of society, as well as showing improvement trends in the measured aspects as reflected in the DEA Malmquist index. As a result, a model is obtained for university administrators to identify the aspects in which they must invest the public budget that guarantees the greater multidimensional efficiency of Colombian public universities.
\end{abstract}

Index terms-Data Envelopment Analysis, Input-Output analysis, multivariate analysis, Quality of education, University.

Resumen - La medición de la eficiencia en las universidades públicas ha sido un tema de interés para investigadores y

This manuscript was sent on October 30, 2020 and accepted on June 02, 2021. It is a scientific research article derived from the doctoral thesis "Model for the improvement of Productive, Distributive, Dynamic and Assignment Efficiencies of Colombian Public Universities" of the Doctorate in Projects of the International Ibero-American University.

W. Arenas-Valencia, Professor of the Industrial Engineering program, Universidad Tecnológica de Pereira, Colombia, Street 27\#10-02. (warenas@utp.edu.co). funcionarios estatales en Colombia; Este artículo presenta un modelo que trasciende la mirada de eficiencia productiva, y la expande al incluir aspectos de equidad a través del cálculo de la eficiencia distributiva, de aceptación por parte de la sociedad con la eficiencia. de asignación, y finalmente al calcular la eficiencia dinámica incluye la variable tiempo, con la que el Estado puede medir la estabilidad de los indicadores de interés. Para el diseño del modelo se utilizaron técnicas estadísticas multivariadas y técnicas no paramétricas, tales como Modelos de Ecuaciones Estructurales, Análisis de Componentes Principales, Análisis Envolvente de Datos y el Cuadro de Mando Integral. Se obtienen diferentes ránquines con los que se identificaron planes de mejoramiento universitario, destacando instituciones públicas con acreditación de alta calidad. Se propone un Cuadro de Mando Integral con los indicadores extraídos de las bases de datos del sector que cumplieron las condiciones de las técnicas utilizadas. Esta técnica sugiere una relación causal entre los indicadores de eficiencia distributiva, productiva y de asignación, donde la perspectiva de inclusión forma la base del cuadro de mando, afectando la perspectiva de la formación y la investigación y esta última incidiendo en la perspectiva de impacto. Finalmente, se concluye que el sistema universitario estatal tiene grandes desafíos en términos de inclusión y medición de la satisfacción de la sociedad, además de mostrar tendencias de mejora en los aspectos medidos reflejados en el índice DEA Malmquist. Como resultado, se obtiene un modelo para que los administradores universitarios identifiquen los aspectos en los que deben invertir el presupuesto público que garantice la mayor eficiencia multidimensional de las universidades públicas colombianas.

Palabras Clave-: Análisis de Entradas y Salidas, análisis multivariado, calidad de la educación, universidad, análisis envolvente de datos.

J.Cabello-Eras, Director of Doctoral Work Universidad IberoAmericana Internacional, Professor, Director of the Department of Energy of the Corporacion Universidad de la Costa, Street 58 \# 55-66 Barranquilla, Colombia. (jjcabe2000@yahoo.com) 


\section{INTRODUCTION}

$\mathrm{C}$ OLOMBIAN public universities have a heterogeneous quality, as stated by Melo-Becerra and others [1] and following what was stated by Rincón [2], they generally show deficits in their budgets, for which it is necessary to optimize their use. A traditional measure of rationality in the use of resources has been efficiency, however in the specialized literature only studies on productive efficiency are reported, leaving out other components such as distributive, dynamic, and allocative efficiencies that, in the case of public service, results in what, according to Andrews and Entwistle, is a reductionist look, where the administration's strategies end in the optimization of the cost-benefit relation [3], without taking into account equity, future generations, and the certainty that public resources are being located where their use is the most productive and satisfactory.

Additionally, public universities are characterized by being institutions which are difficult to administer, given the complexity of their processes [4]. They are institutions of a complex nature; the approach to their management is given from the perspective of the variety of people involved with particular interests in public service as expressed by Houston; the university is seen from educational, social, political, and economic points of view, by academics, students, and other internal actors. At the same time, it is viewed from the outside by employers, citizens, politicians, potential students, parents, and a wide range of other stakeholders [5].

On the other hand, the Colombian government and the universities have invested resources in an institutional accreditation system, which when implemented generates quality improvement plans that must be executed by the different units in order to guarantee their continuous improvement processes, and the documentary review did not find a study that shows how to use this system to improve the efficiencies of higher education institutions in Colombia.

\section{METHODOLOGY}

In this research, quantitative data were used to design an improvement model of accredited public universities that accounts for the quantitative information available from the variables of productivity, well-being, satisfaction, and their impact over time, referring to productive, distributive, allocative, and dynamic efficiency respectively.

A mixed research method was used, which combined qualitative and quantitative techniques to strengthen the resulting inferences; the use of a single approach is insufficient to deal with the complexity [6]. The scope of the research is sequential explanatory, where it begins with the collection of quantitative data, they are analyzed, and then qualitative data are collected, and finally they are integrated for an interpretation [6], Fig. 1 shows the methodology used in this article.

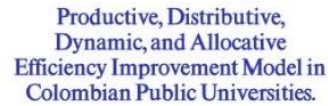

Colombian Public Universities.

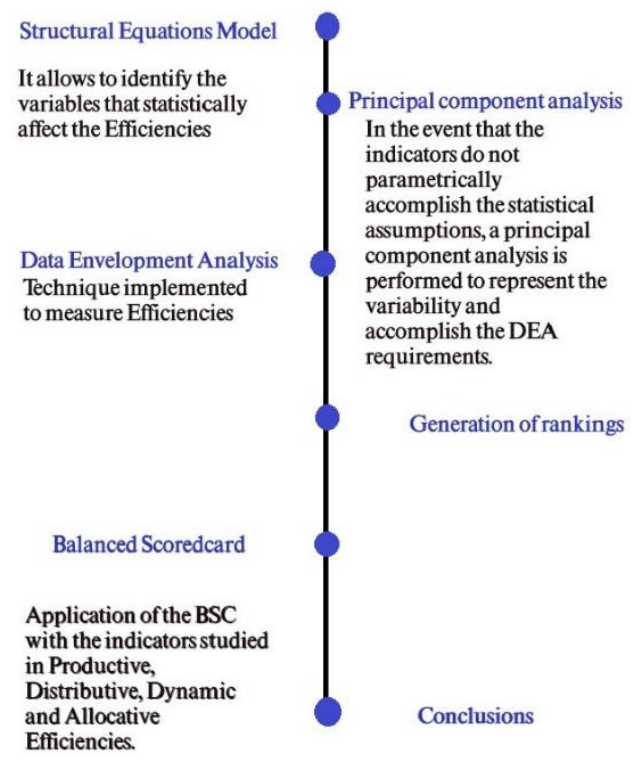

Fig. 1. Methodology implemented for the development of research

In this work specifically, information is collected on the most relevant variables that affect the efficiencies of highquality accredited Colombian public universities, a quantitative method is identified for its analysis, proposed from a review of tools that better adapts to its complexity, since traditional models do not take this into account [7]

Data was analyzed using quantitative analysis techniques such as Structural Equation Models (SEM), Data Envelopment Analysis (DEA), and Balanced Scorecard (BS), parametric and non-parametric statistical tools that complement each other. The Atlas.Ti software was used for the identification of the model and the integration of the bibliographic and qualitative data, the $\mathrm{R}$ statistical software was used for the efficiency calculations, and the PLS-SMART software for the structural equation models.

\section{A. Structural Equations.}

The Structural Equation Modeling (SEM) technique is often used for theoretical confirmations; it is a quantitative method that is currently used to test theoretical models and establish causal relationships between latent variables that are considered unobserved, and observable variables, as described by Littlewood and others [8].

From the perspective of these authors[8], the SEM presents a combination between statistical data and causal assumptions; it is a statistical method that starts from multiple regression, examining the correlations between variables, and the analysis of the information. 
Therefore, the SEM is a widely used alternative due to the breadth of the analysis, the causal relationship between the variables, and the validation of hypothetical models.

This approach allows one to test or confirm theories; therefore, it is used as a confirmatory position, unlike other types of statistical analysis such as exploratory factor analysis.

In this way, the SEM technique determines the relationship between the variables of the different efficiencies (productive, distributive, allocative, and dynamic), and the global efficiency, which in a statistical way allows the researcher to verify practically he relationships and causal factors between the variables of efficiencies and global efficiency, in order to corroborate the theories put forward by Andrews and Entwistle [3], based on data from Colombian public universities.

\section{B. Data Envelopment Analysis -DEA.}

DEA is an optimization tool, used to compare decision units with an objective at the frontier; this unit is considered from best practices based on the current data set [9]. Considering this approach, DEA is one of the non-parametric techniques that allows comparisons to be made based on the available information, without having a predetermined behavior pattern.

The efficiency of every decision unit under consideration using the DEA criterion is based on two components, the first considers technical efficiency, that is, the ability to obtain the maximum output with a given set of inputs, and the second component is derived from the optimal distribution of the inputs considering their cost [9].

From the research of Chandrasekar and others[9], the DEA technique considers the measurement of efficiency from two sides, the model based on inputs, considering the possibility that decision units reduce the number of inputs while maintaining the same number of outputs, and the output-based model, which considers the possibility of expanding the number of outputs with the same level of inputs.

DEA requires a minimum number of decision-making units (DMU) to be able to discriminate the DMU located on the frontier, according to Cooper, Seiford, and Kaoru [10] the number of DMU $n$ must accomplish the following expression:

$n>\max (m * s, 3 *(m+s))$

$\mathrm{m}$ is the number of inputs and $\mathrm{s}$ the number of outputs, directly related to the number of variables to be included in the analysis, so that the boundary line can be generated, which specifies the decision units with the highest degree of efficiency, and to compare the relative efficiency between the different decision units, which in the case of this research are public universities in Colombia.

\section{Balanced Scorecard-BS.}

One of the proposals of the authors Andrews, Entwhistle et al [3] to complement the statistical analysis presented in the measurement and improvement of efficiency, is the application of non-frontier techniques such as the Balanced Scorecard (BS) that enable the comprehensive vision of the system from improvement plans that include indicators related to the mission objectives of the organizations.

One of the elements to be considered as an advantage of applying the BS [11] is to find a cause-effect relationship between the indicators, which is why it is used in complement with the statistical techniques mentioned above and precisely with the Structural Equation Model that allows the confirmation of theories taking into account the causal relationships between variables.

\section{DEA Malmquist.}

The Malmquist index was originally proposed by Malmquist, Caves, and Christensen in 1953 and Diewert in 1982, explained by $\mathrm{Li}$ et al. [12]. It is used to calculate the dynamic efficiency. The index is applied to calculate the change in production efficiencies in various periods of time. In 1994, Rolf, Fare et al. quoted by [13] linked a nonparametric linear programming method with the theory of data envelopment analysis (DEA) to develop the DEA Malmquist index analysis method 13]. The Malmquist index (MI) can be calculated using (2)

$$
M I=\left[\frac{\delta^{1}\left(\left(x_{0}, y_{0}\right)^{2}\right.}{\delta^{1}\left(\left(x_{0}, y_{0}\right)^{1}\right.} * \frac{\delta^{2}\left(\left(x_{0}, y_{0}\right)^{2}\right.}{\delta^{2}\left(\left(x_{0}, y_{0}\right)^{1}\right.}\right]^{1 / 2}
$$

The first term evaluates the quotient of the efficiency with respect to the frontier of period 2 over the efficiency of period 1 , and the second factor measures the effect of the change in the frontier observed in the second period.

In (2) refers to the efficiency frontier of the first period and to the efficiency frontier of the second period. is the input vector, the output vector of the observed decision unit, and the superscript $t$ indicates whether the inputs and outputs have been observed in period 1 or 2

Each efficiency $(s=1,2)$ is calculated by running an outputoriented DEA VRS model.

Data from reports to the Colombian Ministry of National Education were used, for which university web pages, reports from the System of State Universities [2] the National Information System for Colombian Higher Education (SNIES) [14] and the Higher Education Performance Indicators Model (MIDE) [15] were used and a compilation table was made.

\section{RESULTS}

This research evidenced that there are several information systems that contain data from public universities, which the Colombian state keeps updated, since it is considered that they describe the productivity of their operation, these information systems are:

Higher Education Indicators Model (MIDE); System for the Prevention of Dropout in Institutions of Higher Education (SPADIES), National Information System of Higher Education (SNIES); Financial Model State University System (SUE). Likewise, a lack of information is evidenced in two of the facets 
of efficiencies in the public service, named in this study, such as distributive efficiency and allocation efficiency.

The inputs for productive efficiency, allocative and distributive efficiencies were chosen with the criteria of financial, physical and human talent resources, which universities use at the first level to generate their operation against the public service of higher education.

The outputs for productive efficiency were made up of the results of the interaction of resources and the institutional mission in the face of training and research.

The outputs of distributive efficiency were identified from state databases, which were related to issues of equity, gender, leaving out indicators of ethnic cultural diversity and people with physical disabilities. Which are not collected by state information systems. Then value-added indicators were used that compare the initial conditions of the students and the final conditions against their academic performance, as well as the number of students in vulnerable socioeconomic strata and the number of women in the institutions.

The outputs of the allocation efficiency, which was linked to society's satisfaction with the public service of higher education, provide an indirect measurement, since there are no generalized state measurements of satisfaction with public universities. In this way, factors such as percentage of students registered over matriculated, social appropriation of knowledge and employability were taken.

Finally, the dynamic efficiency took the performance of the previous efficiencies during the years 2016, 2017 and 2018 measured with the Malmquist index.

Through the structural equations, it is sought to confirm that the entries in the universities are reflected in the total teaching, administrative and budget execution indicators and that these are the cause of the products or outputs such as the results of the students in the state tests or the social appropriation of knowledge among others. Fig. 2 shows an output of the PLSSMART software used to calculate the structural equation.

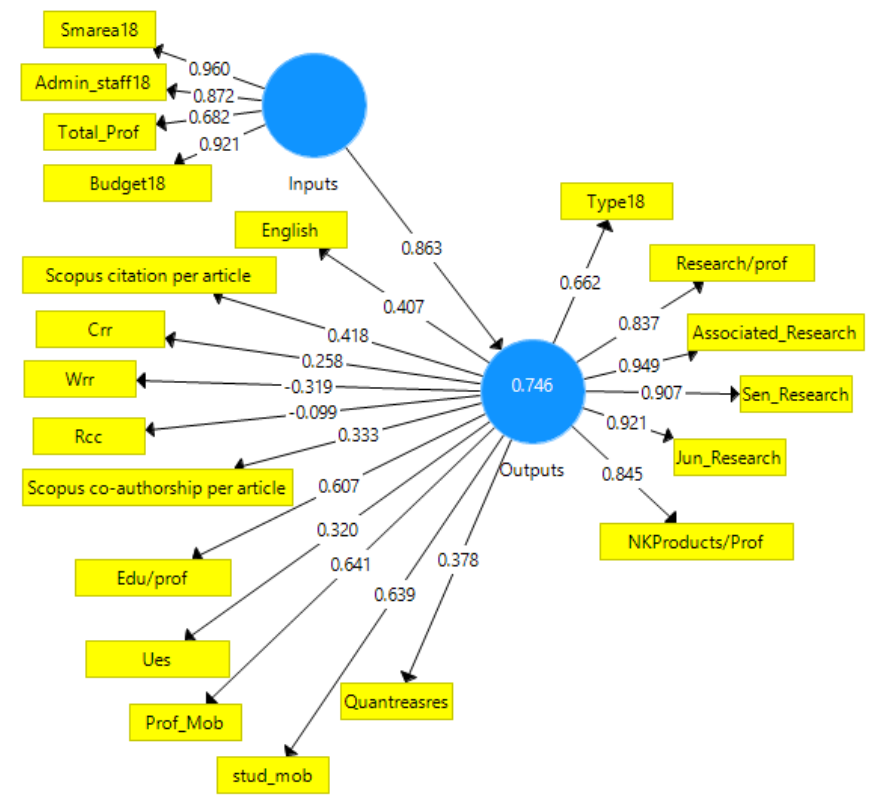

Fig. 2. General Structural Equations Model.

The indicators with loads greater than or equal to 0.7 (rounded to 1 decimal) are chosen according to Sadidi, Khalilifar, Amiri, and Moradi [16] which for the inputs will be: area in square meters (Smarea18), budget 2018 (Budget18), total professors (Total_Prof), and administrative staff 2018 (Admin_staff18) and for the output the resulting indicators are: type of university 2018 (Type18), researchers per professor (Research/prof), associated researchers (Associated_Research), junior researchers (Jun_Research), senior researchers (Sen_Research), and new knowledge products per professor (NKProducts/Prof.). From this result it is identified that the indicators that have the most burden in the productive efficiency model are those associated with the research function, therefore alternative methodologies should be sought to apply to the indicators that best respond to education issues.

Continuing the analysis with productive efficiency, now with only research components from now on (PE_Research18).

Next, the PLS-SEM model is formalized with the indicators that showed the best loads and accomplished the quality and adjustment criteria; the results are shown in Fig. 3:

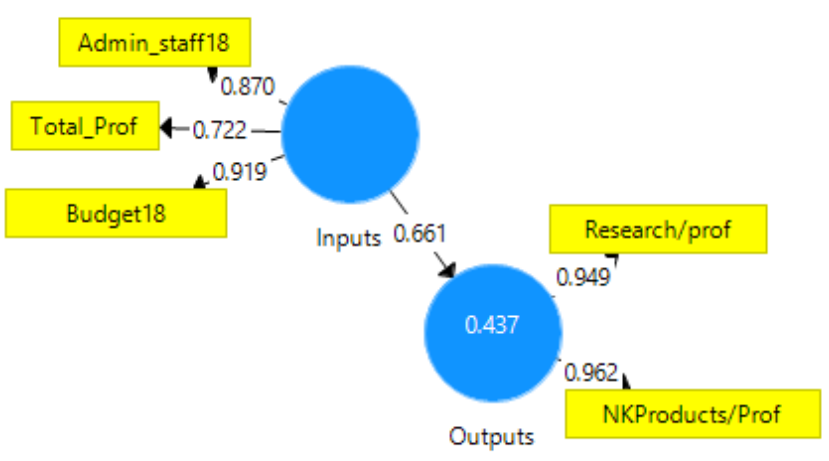

Fig. 3. Structural Equations Model refined.

The collinearity statistics are shown in table I.

TABLE I

COLLINEARITY Statistics OF THE STRUCTURAL Equations Model

\begin{tabular}{lr}
\hline \hline \multicolumn{2}{c}{ VIF values of the external model } \\
\hline Admin_staff18 & 1,807 \\
Total_Prof & 1,632 \\
Budget18 & 2,511 \\
Research/prof & 3,157 \\
NKProducts/Prof & 3,157 \\
\hline \hline
\end{tabular}

Table II shows the indicators that constitute the research productive efficiency:

TABLE II

INDICATORS OF RESEARCH PRODUCTIVE EFFICIENCY

\begin{tabular}{|c|c|c|}
\hline Indicator & Description & Type \\
\hline Total_Prof & Total Professors & Input \\
\hline Admin_staff18 & Total of administrative stuff & Input \\
\hline Budget 18 & Budget in 2018 & Input \\
\hline Research/prof & Researcher per professors & Output \\
\hline NKProducts/Prof & $\begin{array}{l}\text { New knowledge products per } \\
\text { professor }\end{array}$ & Output \\
\hline
\end{tabular}


Once the criteria are accomplished, the DEA Ranking is constructed, and different DEA models present in the literature are explored, finding that for the 2018 data the DEA SBM VRS model, oriented to outputs, is the one that best describes the relationship between the state universities in Colombia, given that it takes into account the size of the institution and excludes from the frontier those institutions with slacks equal to zero, that is, they have some shortage in the outputs or excesses in the inputs, using the statistical software R Studio; the ranking is shown in Table III:

TABLE III

Dea Ranking (Sbm Vrs Model) OF Research Productive EFFICIENCY

\begin{tabular}{rrrr}
\hline \hline Rank & Dmu & \multicolumn{1}{c}{ Eff } & Accredited \\
\hline 1 & 1101 & 1 & 1 \\
2 & 1111 & 1 & 1 \\
3 & 1114 & 1 & 1 \\
4 & 1202 & 1 & 1 \\
5 & 1204 & 1 & 1 \\
6 & 1205 & 1 & 1 \\
7 & 1105 & 0,98681 & 1 \\
8 & 1213 & 0,90589 & 1 \\
9 & 1203 & 0,83345 & 1 \\
10 & 1206 & 0,82788 & 1 \\
11 & 1121 & 0,82462 & 0 \\
12 & 1113 & 0,79666 & 1 \\
13 & 1112 & 0,77965 & 1 \\
14 & 1207 & 0,76152 & 0 \\
15 & 1208 & 0,64322 & 1 \\
16 & 1209 & 0,64058 & 0 \\
17 & 1201 & 0,63221 & 1 \\
18 & 1301 & 0,5743 & 1 \\
19 & 1117 & 0,531 & 1 \\
20 & 1115 & 0,49587 & 0 \\
21 & 1106 & 0,47699 & 1 \\
22 & 1110 & 0,4502 & 1 \\
23 & 1120 & 0,34429 & 0 \\
24 & 1212 & 0,26058 & 0 \\
25 & 2102 & 0,17908 & 0 \\
26 & 1118 & 0,17015 & 0 \\
27 & 1214 & 0,13657 & 0 \\
\hline Frontier Universities without \\
Institutional Accreditation due to \\
\multicolumn{4}{c}{ low budget effect. } \\
\hline na & 1119 & 1 & 0 \\
na & 1122 & 1 & 0 \\
na & 1217 & 1 & 0 \\
na & 1218 & 1 & \\
na: rank does not apply & \\
\hline \hline & \multicolumn{1}{c}{} \\
\hline
\end{tabular}

From this Ranking, it is identified that 4 non-accredited universities appear on the efficiency frontier, due to the low budgets they have compared to others; DEA takes into account the intensive use of the budget so it places them on the efficient frontier. Given that this research is associated with quality systems and mature self-evaluation processes are required, institutions that do not present institutional accreditation from the Colombian Ministry of Education will be removed from the frontier.

DEA better places the University with code DMU 1111 than 1203, which in the Colombian university context is better located (for example: in the Scimago ranking) because the DEA ranking is based on efficiencies, which implies the resources invested to generate production are taken into account; in this sense the 1111 represents $29 \%$ of the budget of the 1203 .

DEA returns improvement plans based on the gaps as shown in Table IV:

TABLE IV

Plan TO IMPROVE UNIVERSITIES TO REACH THE FrontIER OF RESEARCH PRODUCTIVE EFFICIENCY

\begin{tabular}{r|rrr}
\hline \hline DMU & \multicolumn{1}{c}{ Eficiency } & New knowledge & \multicolumn{1}{c}{ Researchers } \\
\hline 1101 & 1,0000 & 0,0000 & 0,0000 \\
1111 & 1,0000 & 0,0000 & 0,0000 \\
1114 & 1,0000 & 0,0000 & 0,0000 \\
1202 & 1,0000 & 0,0000 & 0,0000 \\
1204 & 1,0000 & 0,0000 & 0,0000 \\
1205 & 1,0000 & 0,0000 & 0,0000 \\
1105 & 0,9868 & 0,0000 & 3,1282 \\
1213 & 0,9059 & 0,1020 & 0,0000 \\
1203 & 0,8335 & 0,5038 & 103,3161 \\
1206 & 0,8279 & 0,0991 & 23,6224 \\
\hline \hline
\end{tabular}

Table IV shows the indicators that universities must improve to reach the efficiency frontier, such as the case of the university with code 1203 , which should increase by $8 \%$ the professors dedicated to research represented by 104 (in table IV 103,3161) professors and 1 product of new knowledge; at this point it is important to state that for 104 professors to have the category of researchers, according to the Colombian state, they must produce at least one product of new knowledge during their postgraduate study and 4 in the last 5 years, for which the indicator of new knowledge in practice would increase by at least 104. The strategies that should be implemented for this achievement will be analyzed during the remainder of the paper.

To illustrate the above, a simulation is carried out where University 1203 implements the proposed improvement plan, and the others are assumed to have the same performance in 2018; it is confirmed that the university taken as an example reaches the efficiency frontier as shown in table V:

TABLE V

\begin{tabular}{crr} 
RESEARCH PRODUCTIVE EFFICIENCY SIMULATION \\
\hline DMU & eff & Accredited \\
\hline 1101 & 1 & 1 \\
1111 & 1 & 1 \\
1114 & 1 & 1 \\
1119 & 1 & 0 \\
1122 & 1 & 0 \\
1201 & 1 & 1 \\
1202 & 1 & 1 \\
1203 & 1 & 1 \\
1204 & 1 & 1 \\
1205 & 1 & 1 \\
1217 & 1 & 0 \\
1218 & 1 & 0 \\
1105 & 0,98681 & 1 \\
1213 & 0,90589 & 1 \\
\hline
\end{tabular}

which shows a route to be taken in the improvement plan where the inclusion of professors in the research processes proposed by the Ministry of Science, Technology, and Innovation of Colombia, and thus the creation of products of new knowledge, should be prioritized. 
Regarding the education indicators that were excluded from the model due to the effects of the statistical requirements of the structural equations, the principal components technique with DEA was used; Table VI shows the indicators that make up the education productive efficiency:

TABLE VI

INDICATORS OF THE PRODUCTIVE EFFICIENCY OF EDUCATION

\begin{tabular}{|c|c|c|}
\hline Indicator & Description & Type \\
\hline Total_Prof & Total professors & Input \\
\hline Admin_staff18 & Administrative staff 2018 & Input \\
\hline Budget 18 & Budget in 2018 & Input \\
\hline Smarea18 & Square meters area & Input \\
\hline Type18 & Type of university 2018 & Output \\
\hline Avqr & $\begin{array}{l}\text { Added value of Quantitative } \\
\text { Reasoning (Saber pro statal test) }\end{array}$ & Output \\
\hline Aver & $\begin{array}{l}\text { Added value of critical reading (Saber } \\
\text { pro statal test) }\end{array}$ & Output \\
\hline Qrr & $\begin{array}{l}\text { Quantitative Reasoning Result (Saber } \\
\text { pro statal test) }\end{array}$ & Output \\
\hline Crr & $\begin{array}{l}\text { Critical Reading Result (Saber pro } \\
\text { statal test) }\end{array}$ & Output \\
\hline Wrr & $\begin{array}{l}\text { Written Communication Result } \\
\text { (Saber pro statal test) }\end{array}$ & Output \\
\hline Rec & $\begin{array}{l}\text { Result of Citizen Competencies } \\
\text { (Saber pro statal test) }\end{array}$ & Output \\
\hline Edu/prof & Education per professor & Output \\
\hline Ues & Undergraduate enrolled students & Output \\
\hline English & English results (Saber pro statal test) & Output \\
\hline
\end{tabular}

When applying the principal components technique, 10 components are generated which are decanted into a component by applying the sedimentation graph of Fig. 4.

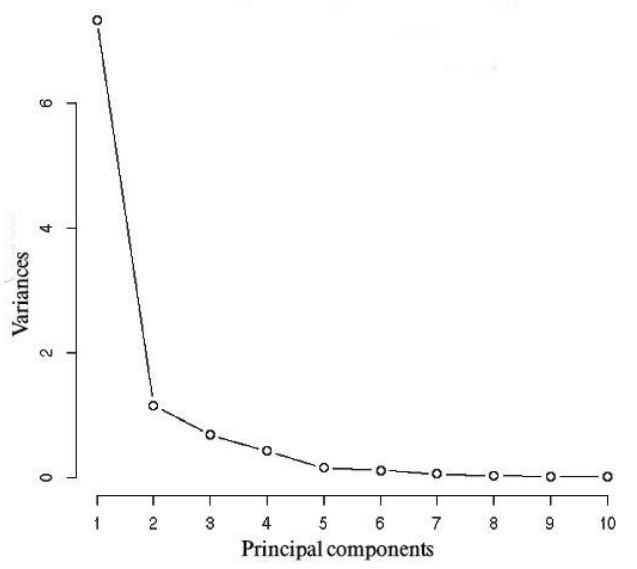

Fig. 4. Formation Productive Efficiency Sedimentation Chart.

Fig. 4. indicates that component one (CP1) is sufficient to represent the variability of the education output indicators.

This component is made up of indicators as shown in (3):

$C P 1=-0,36 *$ Crr $-0,35 *$ English $-0,35 *$ Rcc $0,35 *$ Wrr $-0,35 *$ Qrr $-0,33 *$ Avqr $-0,33 *$ Avcr $0,29 *$ Type $18-0,29 *$ Edu/prof

(3)

The same treatment had the indicators used as inputs for the calculation of the productive efficiency of education.

When applying a DEA-SBM VRS model with the components, the results shown in Table VII are obtained:
TABLE VII

Ranking Dea Model Sbm Vrs Productive EfFiciency OF EDUCATION

\begin{tabular}{rrrr}
\hline \hline Position & \multicolumn{1}{c}{ Dmu } & \multicolumn{1}{c}{ Eff } & Acreditted \\
\hline 1 & 1101 & 1 & 1 \\
2 & 1106 & 1 & 1 \\
3 & 1110 & 1 & 1 \\
4 & 1111 & 1 & 1 \\
5 & 1112 & 1 & 1 \\
6 & 1201 & 1 & 1 \\
7 & 1203 & 1 & 1 \\
8 & 1205 & 1 & 1 \\
9 & 1217 & 0,9371 & 0 \\
10 & 1105 & 0,87832 & 1 \\
11 & 1218 & 0,86716 & 0 \\
12 & 1214 & 0,81957 & 0 \\
13 & 2102 & 0,7776 & 0 \\
14 & 1212 & 0,70668 & 0 \\
15 & 1113 & 0,70562 & 1 \\
16 & 1207 & 0,62187 & 0 \\
17 & 1206 & 0,59204 & 1 \\
18 & 1120 & 0,57297 & 0 \\
19 & 1119 & 0,54337 & 0 \\
20 & 1213 & 0,53769 & 1 \\
21 & 1117 & 0,52055 & 1 \\
22 & 1301 & 0,4588 & 1 \\
23 & 1208 & 0,43944 & 1 \\
\hline \hline
\end{tabular}

Thus, for example, the university with code 1208, being of high quality, should increase its indicators as shown in Table VIII:

TABLE VIII

EdUCATION PRODUCTIVE EFFICIENCY IMPROVEMENT Plan, DMU 1208.

\begin{tabular}{lrr}
\hline \hline Indicator & Actual Value & Target \\
\hline Type18 & 2,000 & 4,875 \\
Avqr & 32,669 & 66,753 \\
Avcr & 27,540 & 59,068 \\
Qrr & 141,276 & 183,314 \\
Crr & 143,838 & 183,119 \\
Wrr & 147,551 & 167,040 \\
Rcc & 136,544 & 153,740 \\
Edu/prof & 0,001 & 0,002 \\
Ues & 141,697 & 167,397 \\
English & 15372,000 & 18165,370 \\
\hline \hline
\end{tabular}

Table VIII is constructed by running an evolutionary linear model from MS Excel, which allows, based on the target of the main component, the reaching of improved values for the education indicators.

For example, this university will be recommended to improve its doctoral approach, improve the education results of the Saber pro statal tests of its students, increase the indicator of education per professor, and increase the enrolled students. It is important to clarify that in order to improve these indicators, the university must make more efficient use of its resources and, in turn, the state must increase its budgets, which would make it necessary to keep the calculations and indicators updated.

\section{E. Allocative Efficiency}

The allocative efficiency measures the satisfaction of society with the public service of higher education; in general the state educational system lacks state indicators that measure the satisfaction of both students and graduates, and society in general. From the indicators collected, the same inputs of 
productive efficiency are taken. The output indicators chosen were: social appropriation of knowledge, employability, and percentage of students registered per matriculated, who, in the opinion of the authors, are a measure of the acceptance of society.

When applying the methodology described using structural equations, the results shown in Fig. 5 are obtained:

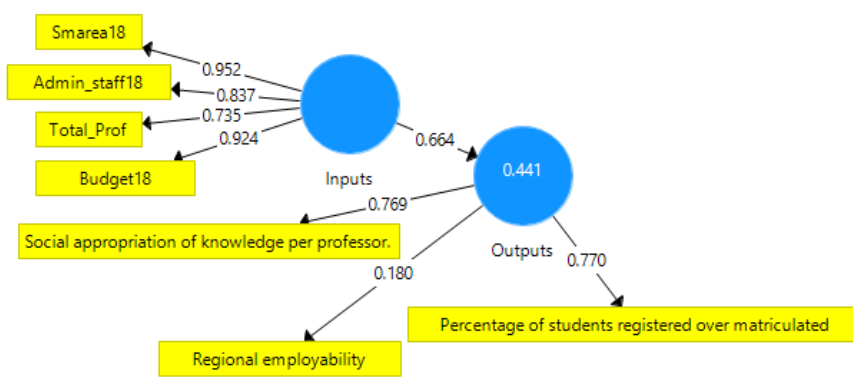

Fig. 5.General Allocative Efficiency Structural Equation Model

The Employability variable does not have the appropriate load that must be greater than 0.7 , and so the definitive model is the one presented in Fig. 6:

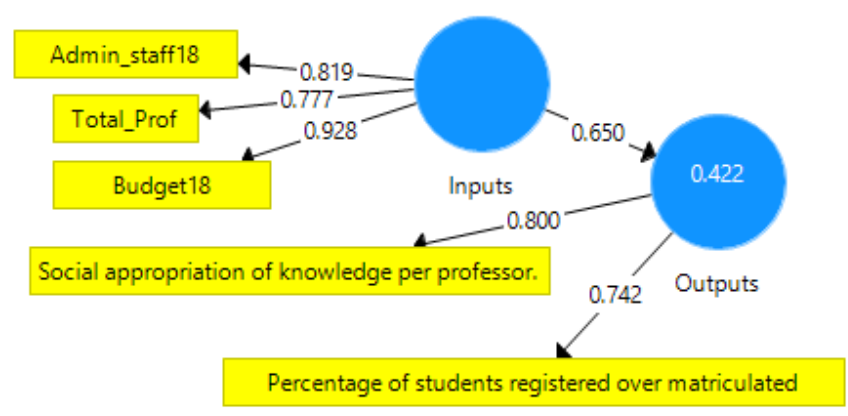

Fig. 6. Refined Allocative Efficiency Structural Equation Model.

When running the DEA SBM VRS model, the ranking of Table IX is obtained:

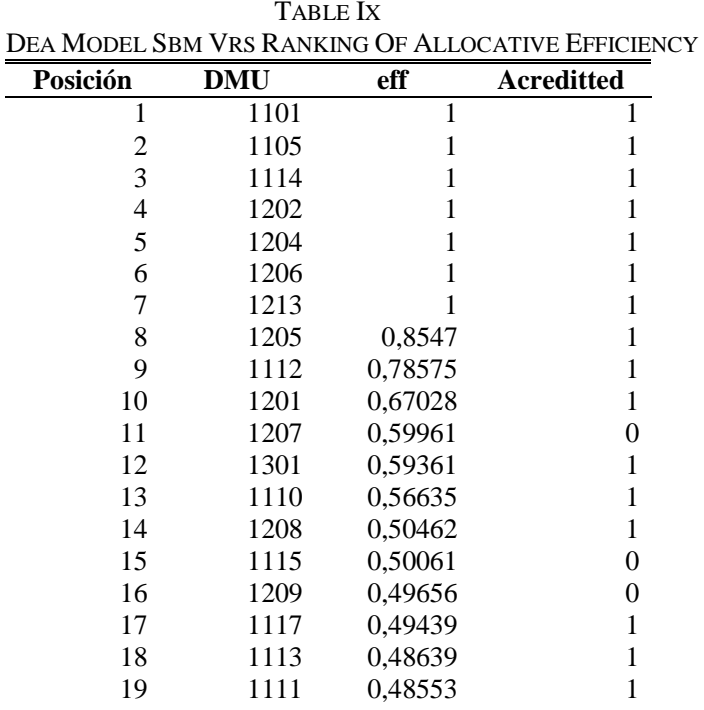

\begin{tabular}{rrrr}
20 & 1120 & 0,46735 & 0 \\
21 & 1106 & 0,42982 & 1 \\
22 & 1214 & 0,40678 & 0 \\
23 & 1212 & 0,39671 & 0 \\
24 & 2102 & 0,34455 & 0 \\
25 & 1118 & 0,2489 & 0 \\
26 & 1203 & 0,15503 & 1 \\
\hline \hline
\end{tabular}

Table IX shows several accredited universities occupying the frontier; the 1203 university stands out, which, being an institution with wide recognition, has low allocative efficiency. When analyzing its improvement plan, it is identified that it has low students registered in its programs, compared to the others, as evidenced in Table X.

TABLE X Plan For IMPROVING THE ALLOCATIVE EFFICIENCY

\begin{tabular}{|c|c|c|c|c|c|c|}
\hline DMU & Total_Prof & $\begin{array}{c}\text { Admin_staf } \\
\text { A18 }\end{array}$ & Budget18 & $\begin{array}{c}\text { Smare } \\
\text { a18 }\end{array}$ & $\begin{array}{c}\text { Socialaprop/ } \\
\text { prof }\end{array}$ & $\begin{array}{l}\text { Regist/ } \\
\text { matric }\end{array}$ \\
\hline 1101 & 0,0 & 0,0 & 0,0 & 0,0 & 0,0 & 0,0 \\
\hline 1105 & 0,0 & 0,0 & 0,0 & $\begin{array}{r}0,0 \\
4581\end{array}$ & 0,0 & 0,0 \\
\hline 1106 & 396,0 & 153,4 & 0,0 & $\begin{array}{r}0,9 \\
6065\end{array}$ & 0,0 & 1,1 \\
\hline 1110 & 228,3 & 253,6 & 0,0 & 1 & 0,0 & 0,0 \\
\hline 1111 & 152,5 & 67,8 & 0,0 & 0,0 & 0,0 & 0,9 \\
\hline 1112 & 173,7 & 179,5 & 0,0 & $\begin{array}{r}0,0 \\
2999\end{array}$ & 0,0 & 0,2 \\
\hline 1113 & 0,0 & 294,4 & 59777,0 & 5,7 & 0,0 & 1,0 \\
\hline 1114 & 0,0 & 0,0 & 0,0 & $\begin{array}{r}0,0 \\
1095\end{array}$ & 0,0 & 0,0 \\
\hline 1115 & 100,5 & 289,7 & 0,0 & $\begin{array}{r}32,9 \\
6430\end{array}$ & 0,0 & 0,6 \\
\hline 1117 & 296,0 & 363,7 & 0,0 & 3,3 & 0,0 & 1,0 \\
\hline 1118 & 216,2 & 18,7 & 13788,7 & 0,0 & 0,0 & 0,6 \\
\hline 1119 & 0,0 & 0,0 & 0,0 & $\begin{array}{r}0,0 \\
1861\end{array}$ & 0,0 & 0,0 \\
\hline 1120 & 152,5 & 0,0 & 0,0 & 60,2 & 0,0 & 0,3 \\
\hline 1121 & 0,0 & 0,0 & 0,0 & 0,0 & 0,0 & 0,0 \\
\hline 1122 & 0,0 & 0,0 & 0,0 & 0,0 & 0,0 & 0,0 \\
\hline 1201 & 1638,9 & 926,2 & 89450,3 & 0,0 & 0,0 & 0,0 \\
\hline 1202 & 0,0 & 0,0 & 0,0 & 0,0 & 0,0 & 0,0 \\
\hline 1203 & 295,8 & 676,8 & 45595,3 & 0,0 & 0,0 & 1,7 \\
\hline 1204 & 0,0 & 0,0 & 0,0 & 0,0 & 0,0 & 0,0 \\
\hline 1205 & 0,0 & 437,7 & 51598,0 & 0,0 & 0,0 & 0,3 \\
\hline 1206 & 0,0 & 0,0 & 0,0 & $\begin{array}{r}0,0 \\
2264\end{array}$ & 0,0 & 0,0 \\
\hline 1207 & 68,2 & 275,7 & 0,0 & 3,4 & 0,0 & 0,7 \\
\hline 1208 & 178,2 & 9,1 & 0,0 & 0,0 & 0,0 & 0,8 \\
\hline 1209 & 52,9 & 96,6 & 0,0 & $\begin{array}{r}0,0 \\
3005\end{array}$ & 0,0 & 0,6 \\
\hline 1212 & 619,7 & 68,9 & 0,0 & 0,3 & 0,0 & 0,0 \\
\hline 1213 & 0,0 & 0,0 & 0,0 & $\begin{array}{r}0,0 \\
2036\end{array}$ & 0,0 & 0,0 \\
\hline 1214 & 122,3 & 161,8 & 0,0 & 5,3 & 0,0 & 0,1 \\
\hline 1217 & 0,0 & 0,0 & 0,0 & 0,0 & 0,0 & 0,0 \\
\hline 1218 & 0,0 & 0,0 & 0,0 & $\begin{array}{r}0,0 \\
9292,\end{array}$ & 0,0 & 0,0 \\
\hline 1301 & 155,1 & 693,7 & 0,0 & 1 & 0,0 & 0,8 \\
\hline 2102 & 1025,1 & 131,1 & 1562,0 & 0,0 & 0,0 & 1,1 \\
\hline
\end{tabular}

Table $\mathrm{X}$ shows the aspects that universities must improve to reach the frontier; in the case of university 1203 it must increase its indicator of students registered per matriculated by 1.7440 , that is, it must go from 4,593 to 54,579, making greater efforts to get the attention of society at the national level.

In the same way, it should improve the social appropriation of knowledge per professor. 


\section{F. Distributive Efficiency}

The distribution of public sector goods or services stands out, especially in terms of equity and justice, considering the proportion of the population most in need, in terms of socioeconomic conditions.

The distributive efficiency indicator was constructed with the variables in Table XI:

TABLE XI

DISTRIBUTIVE EFFICIENCY INDICATORS

\begin{tabular}{|c|c|c|}
\hline Indicator & Description & Type \\
\hline Total_prof & Total professors & Input \\
\hline Admin_staff 18 & Total of administrative staff & Input \\
\hline Budget18 & Budget in 2018 & Input \\
\hline Smarea18 & $\begin{array}{l}\text { Square meters area } \\
\text { Added value of Quantitative }\end{array}$ & Input \\
\hline Avqr & $\begin{array}{l}\text { Reasoning (Saber pro statal } \\
\text { test) }\end{array}$ & Output \\
\hline Aver & $\begin{array}{l}\text { Added value of critical } \\
\text { reading (Saber pro statal test) }\end{array}$ & Output \\
\hline Graduation & Graduation & Output \\
\hline Psst1 & $\begin{array}{l}\text { Percentage of Socioeconomic } \\
\text { Strata } 1\end{array}$ & Output \\
\hline Psst2 & $\begin{array}{l}\text { Percentage of Socioeconomic } \\
\text { Strata } 2\end{array}$ & Output \\
\hline Psst3 & $\begin{array}{l}\text { Percentage of Socioeconomic } \\
\text { Strata } 3\end{array}$ & Output \\
\hline Remained & Remained in the institution & Output \\
\hline Womnum & Women number & Output \\
\hline
\end{tabular}

When analyzing the restriction of DMUs vs number of indicators, it is verified that the statement in (1) is not accomplished, so a model of principal components must be run to reduce the number of variables, and then the DEA technique must be applied; the graph of sedimentation in Fig. 7 shows that four components represent the most important variability of the data in the output.

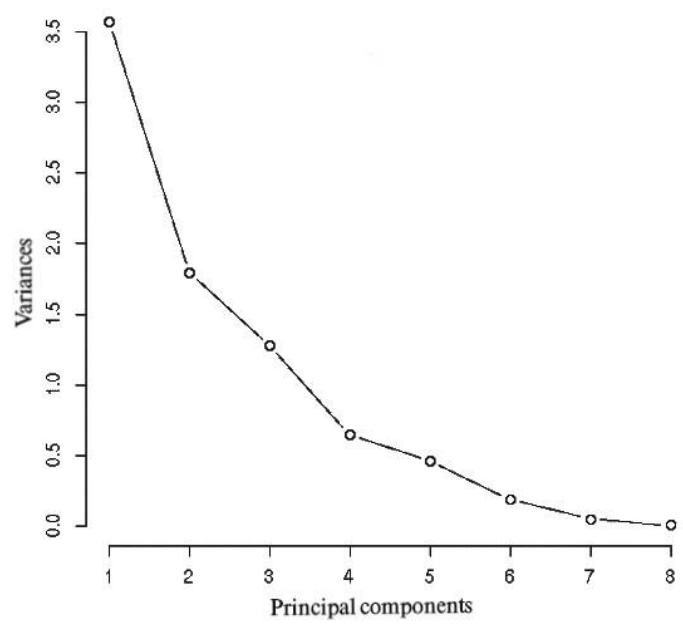

Fig. 7. Sedimentation Graph of Distributive Efficiency.

Table XII shows the component weights:
TABLE XII

MAIN COMPONENTS OF DISTRIBUTIVE EFFICIENCY

\begin{tabular}{lrrrr}
\hline \hline \multicolumn{1}{c}{ Indicator } & \multicolumn{1}{c}{ CP1 } & \multicolumn{1}{c}{ CP2 } & \multicolumn{1}{c}{ CP3 } & \multicolumn{1}{c}{ CP4 } \\
\hline Avqr & $-0,44$ & 0,04 & $-0,41$ & 0,12 \\
Avcr & $-0,39$ & 0,09 & $-0,53$ & 0,18 \\
Graduation & $-0,20$ & 0,33 & 0,49 & 0,67 \\
Psst1 & 0,49 & 0,13 & $-0,26$ & 0,17 \\
Psst2 & $-0,38$ & $-0,10$ & 0,43 & $-0,50$ \\
Psst3 & $-0,47$ & $-0,04$ & 0,06 & 0,08 \\
Remained & $-0,07$ & 0,64 & $-0,18$ & $-0,47$ \\
Womnum & $-0,06$ & $-0,67$ & $-0,14$ & 0,02 \\
\hline \hline
\end{tabular}

On the other hand, from the point of view of the input indicators, the four are reduced to one main component as shown in Fig. 8:

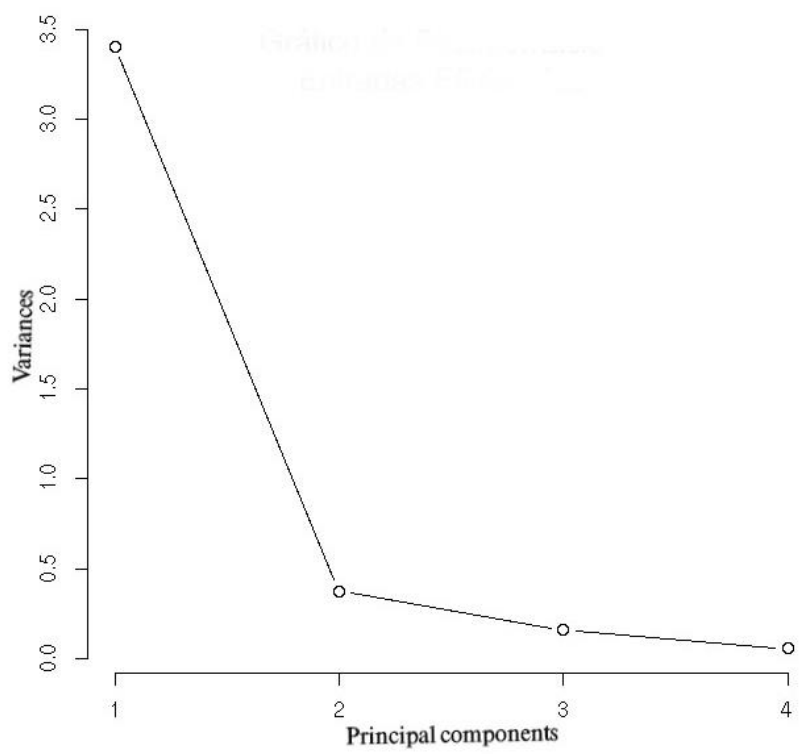

Fig. 8. Sedimentation Graph of Distributive Efficiency

Applying a DEA SBM VRS model with the R software, the ranking obtained is the one shown in table XIII:

TABLE XIII RANKING DeA Model SBM VRS Distributive EFFICIENCY

\begin{tabular}{rrrr}
\multicolumn{1}{c}{ Position } & DMU & \multicolumn{1}{c}{ Eff } & Acreditted \\
\hline 1 & 1101 & 1 & 1 \\
2 & 1105 & 1 & 1 \\
3 & 1110 & 1 & 1 \\
4 & 1113 & 1 & 1 \\
5 & 1117 & 1 & 1 \\
6 & 1203 & 1 & 1 \\
7 & 1205 & 1 & 1 \\
8 & 1206 & 1 & 1 \\
9 & 1207 & 0,98255 & 0 \\
10 & 1208 & 0,97483 & 1 \\
11 & 1201 & 0,89011 & 1 \\
12 & 1202 & 0,78999 & 1 \\
13 & 1119 & 0,72324 & 0 \\
14 & 1204 & 0,68149 & 1 \\
15 & 1120 & 0,66369 & 0 \\
16 & 1112 & 0,63941 & 1 \\
17 & 1122 & 0,58135 & 0 \\
18 & 1114 & 0,56854 & 1 \\
19 & 1301 & 0,50217 & 1 \\
20 & 1213 & 0,50027 & 1 \\
21 & 1214 & 0,3504 & 0 \\
22 & 1106 & 0,28029 & 1 \\
23 & 1209 & 0,27694 & 0 \\
24 & 1111 & 0,25348 & 1
\end{tabular}


25

2102

0,11675

0

In the case of the 1111 university, being accredited, it must carry out an improvement plan to get out of the penultimate place in distributive efficiency; for this an evolutionary model is carried out with the main components. The results for the improvement plan are shown in Table XIV:

TABLE XIV

DMU 1111 IMPROVEMENT PLAN FOR DISTRIBUTIVE EFFICIENCY

\begin{tabular}{lrrr}
\hline \hline \multicolumn{1}{c}{ Indicator } & $\begin{array}{c}\text { Current } \\
\text { result }\end{array}$ & $\begin{array}{c}\text { Modeling } \\
\text { result }\end{array}$ & $\begin{array}{c}\text { Improvement } \\
\text { plan }\end{array}$ \\
\hline Avqr & 57,11553 & 43,55939 & 57,11553 \\
Avcr & 46,62971 & 59,54350 & 59,54350 \\
Graduation & 0,24830 & 0,55751 & 0,55751 \\
Psst1 & 0,20005 & 0,54576 & 0,54576 \\
Psst2 & 0,24665 & 0,35271 & 0,35271 \\
Psst3 & 0,42185 & 0,17232 & 0,42185 \\
Remained & 0,91250 & 0,95290 & 0,95290 \\
Womnum & 6924 & 8780,16129 & 8780,16129 \\
\hline \hline
\end{tabular}

The Model Result column shows the outputs of the evolutionary algorithm run in MS Excel, the Improvement Plan column shows the target values of the indicators; for this case five indicators must improve, added value of critical reading, graduation, students in strata 1 and 2 , and the number of women studying at university.

From the perspective of efficiencies, the calculation of dynamic efficiency remains.

\section{G. Dynamic Efficiency}

This efficiency contemplates the transition of the different efficiency approaches (productive, allocative, and distributive efficiency) over the years; for this research the years 2016, 2017, and 2018 are considered. It is highlighted that, in these years, there has particularly been a change in the calculation of the citizen competencies indicator, for which in 2016 a proxy indicator was used, built with linear regression.

For the analysis of dynamic efficiency, if the Malmquist index is greater than 1 , the university shows an improvement over time, otherwise it would be in a downward trend in the period studied. In the case of public universities in Colombia in the 2016-2018 period, efficiencies showed the trend shown in Table XV:

TABLE XV

DyNAMIC EFFICIENCY RESUlts Through The APPliCATION OF The MALMQUIST INDEX

\begin{tabular}{rrrrr}
\hline \hline \multicolumn{1}{l}{ DMU } & Research & Education & Distributive & Assignative \\
\hline 1101 & 1,1174 & 1,3492 & 0,9441 & 1,2285 \\
1105 & 1,0660 & 1,2542 & 1,2226 & 1,0767 \\
1106 & 1,0000 & 0,9487 & 0,9825 & 0,9996 \\
1110 & 1,0000 & 0,9174 & 1,0013 & 1,1583 \\
1111 & 1,0464 & 0,9974 & 1,1442 & 0,8396 \\
1112 & 1,0000 & 0,9643 & 1,0207 & 0,9387 \\
1113 & 1,0070 & 0,9692 & 1,0380 & 0,9372 \\
1114 & 1,1732 & 1,1461 & 1,2034 & 1,0447 \\
1115 & 1,0000 & 0,9360 & 0,9146 & 0,9416 \\
1117 & 1,0000 & 0,8938 & 0,9977 & 0,9375
\end{tabular}

\begin{tabular}{ccccc}
1118 & 1,0000 & 0,9914 & 0,9895 & 0,6934 \\
1119 & 0,9810 & 1,0490 & 0,9983 & 1,0802 \\
1120 & 1,0000 & 0,9896 & 0,9827 & 0,9793 \\
1121 & 1,0000 & 0,9911 & 0,9927 & 0,8907 \\
1122 & 1,0000 & 0,9262 & 0,9221 & 0,8158 \\
1201 & 1,0000 & 1,0898 & 1,0004 & 1,0098 \\
1202 & 1,0310 & 1,0052 & 0,9901 & 1,2276 \\
1203 & 1,0040 & 0,9903 & 0,9934 & 0,8523 \\
1204 & 1,0458 & 1,0517 & 1,0711 & 1,1760 \\
1205 & 1,0378 & 0,9370 & 1,1730 & 1,0223 \\
1206 & 0,9871 & 0,9083 & 0,9437 & 0,9142 \\
1207 & 1,0000 & 1,0909 & 1,0444 & 1,1194 \\
1208 & 1,0000 & 1,0433 & 1,0618 & 0,9769 \\
1209 & 1,0000 & 1,0895 & 1,1092 & 0,8777 \\
1212 & 1,0000 & 1,0139 & 1,0118 & 1,1800 \\
1213 & 1,0000 & 0,9102 & 0,9323 & 1,1315 \\
1214 & 1,0000 & 0,9722 & 0,9916 & 1,2902 \\
1217 & 0,8822 & 1,0188 & 0,9238 & 1,1304 \\
1218 & 1,1639 & 0,9820 & 0,9642 & 1,4808 \\
1301 & 1,0000 & 1,0405 & 1,1589 & 0,9643 \\
2102 & 1,0000 & 0,9849 & 1,0300 & 1,0111 \\
Average & 1,0175 & 1,0146 & 1,0243 & 1,0299 \\
StdDev & 0,0537 & 0,0982 & 0,0830 & 0,1603 \\
pvalue & 0,0348 & 0,2042 & 0,0513 & 0,1496 \\
\hline \hline
\end{tabular}

With the data collected for this work with a significance of $5 \%$, only research efficiency in the public university sector reports improvement; also with a significance of $10 \%$ the distributive efficiency has improved, and regarding the efficiency of satisfaction and education great challenges still persist in the sector. Five institutions show improvements over time, in the aspects analyzed in this research, which proposes that the state should motivate and support the proposed improvement plans.

\section{H. Balanced Scorecard}

To identify the predominant categories in the reviewed literature, the Atlas.Ti software was used, the result of which is shown in Fig. 9.

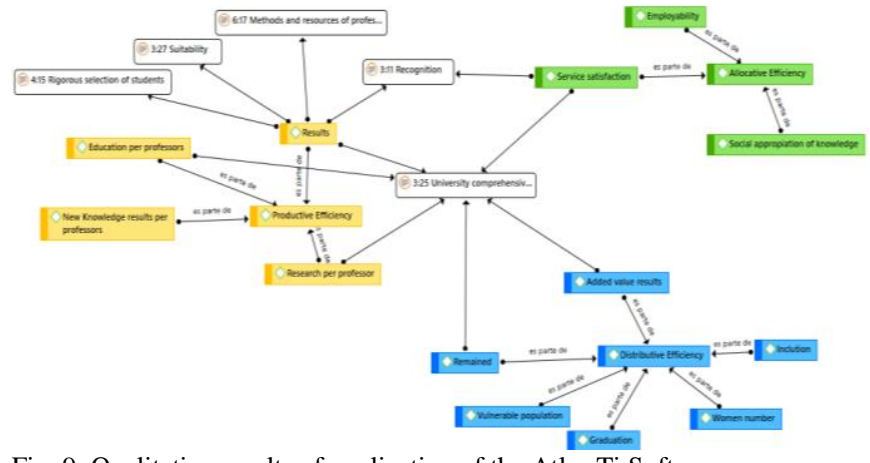

Fig. 9. Qualitative results of application of the Atlas.Ti Software

Fig. 9 evidences three perspectives that contrast the classic conception of a BS, which generally proposes four: Learning and Growth Perspective, Internal Processes Perspective, Clients' Perspective, and Financial Perspective. However, these categories may vary in type and quantity according to the business or mission objective outlined in the strategy. As these are public educational institutions, the strategy differs from the classic business purpose where the main objective of any profitmaking organization is to obtain financial profits (Financial Perspective), it being necessary to consider other objectives 
such as quality in the education or the same impact generated by the institution in the region and society as shown in Fig. 9 .

Taking into account the above, three perspectives have been determined in the BS for the improvement of the efficiencies of Colombian public universities: the Inclusion perspective, Research and Education perspective, and the Impact perspective, the last one as the main objective of the institutions that monitor society's satisfaction with public services. The above is shown in table XVI.

TABLE XVI

BALANCED SCORECARD RESULTS

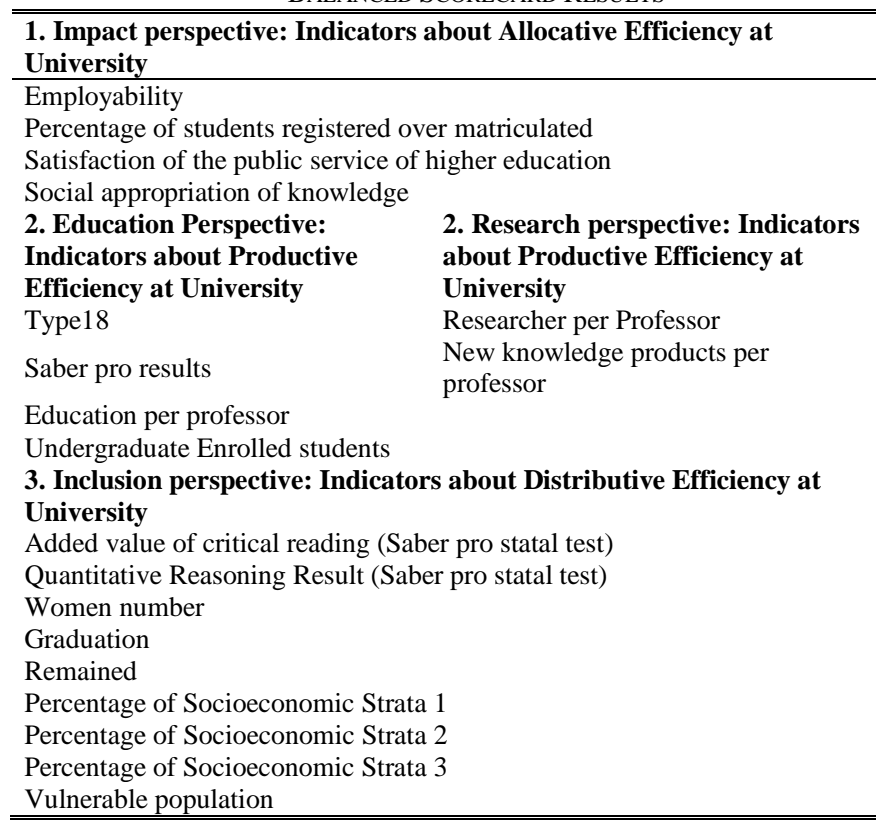

For public universities to fulfill their mission, the perspective of inclusion must positively affect that of education and research and this in turn impact the satisfaction that society has, however, for example, with regard to students in stratum 1, it negatively affects the results of the Saber pro statal tests as is evidenced by the negative slope of the correlation carried out, so the support and well-being services must be articulated with the academic education processes to positively influence the effect of the students of socioeconomic stratum 1 .

\section{CONCLUSIONS}

This study confirms relevant positions of some Colombian universities and proposes a guide methodology in which nonfrontier universities continue to improve and impact society.

It is evident that the resources allocated by the Colombian state are being used in a thriving sector that improves or preserves its efficiency in the four aspects of public service interest.
The usefulness of complementing statistical techniques with linear programming models, which enrich data analytics, is confirmed.

The model used in this research provides rankings that can be used for the improvement of the institutions that, in addition to the products, also take into account the resources and sizes of the institutions.

It is identified that universities must increase their efforts to improve their academic quality, so that student performance is reflected in the state tests, as well as focus their efforts on masters and doctorate programs.

\section{RECOMMENDATION}

The State Educational System must be provided with indicators that record the satisfaction of society with the public education service provided by the universities, to generate action and improvement plans that impact the allocative efficiency of the institutions.

This research identifies distributive efficiency as a key aspect, so the indicators of the inclusion perspective should be strengthened in public universities, which is reflected, not only in the access to higher education of the vulnerable population, but also in their permanence and graduation success shown in state test results, employability, and satisfaction of society with universities.

The proposed models give input to future research on causality analysis of the Balanced Scorecard, which monitors the improvement of productive, distributive, allocative, and dynamic efficiencies in universities, as well as the calculation of these efficiencies within each university, taking academic programs as decision units.

\section{REFERENCES}

[1] L. A. Melo-Becerra, J. E. Ramos-Forero, and P. O. HernándezSantamaría, "La educación superior en Colombia: situación actual y análisis de eficiencia <sup/>," Rev. Desarro. y Soc., no. 78, pp. 59111, 2017. DOI: 10.13043/DYS.78.2

[2] T. Rincón Laverde, "Sistema Universitario Estatal Colombiano: características del SUE y de la Educación Superior en Colombia," 2015.

[3] R. Andrews and T. Entwistle, Public service efficiency: Reframing the debate. 2014.

[4] U. Ferriol, Fermin, "En torno al perfeccionamiento de la dirección estratégica en las Instituciones de la Educación Superior (IES).," vol. 13 (4), no. Folletos Gerenciales, pp. 84-95, 2010.

[5] D. Houston, "Achievements and consequences of two decades of quality assurance in higher education: A personal view from the edge," Quality in Higher Education, vol. 16, no. 2. pp. 177-180, 2010. DOI: 10.1080 / 13538322.2010 .485730

[6] R. Hernández Sampieri, C. Fernandez Collado, and M. del P. Baptista Lucio, "Metodologia de la investigación." México, p. 752, 2018.

[7] S. R. Clegg, C. Hardy, T. B. Lawrence, and W. R. Nord, Tratado de estudios organizacionales. USA, 2017.

[8] H. F. Littlewood Zimmerman and E. R. Bernal García, Mi primer modelamiento de Ecuación Estructural, April 2011. Mexico, 2011. 
[9] V. Chandrasekar, S. Ramadas, and P. Ramasundaram, "Data Envelopment Analysis," Multi-Criteria Decis. Anal. Methods Softw., no. march, pp. 82-86, 2017.

[10] W. W. Cooper, L. M. Seiford, and J. Zhu, Eds., Handbook on Data Envelopment Analysis, vol. 71. Boston: Kluwer Academic Publishers, 2004.

[11] P. Rodrigues Quesado, B. Aibar Guzman, and L. Lima Rodrigues, "Las relaciones de causa y efecto y el diseño de mapas estratégicos: un estudio empírico en organizaciones públicas y privadas portuguesas," Port. J. Financ. Manag. Account., vol. 3, no. 5, pp. 91115, 2017.

[12] J. Li, J. Zhang, L. Gong, and P. Miao, "Research on the Total Factor Productivity and Decomposition of Chinese Coastal Marine Economy: Based on DEA-Malmquist Index," J. Coast. Res., 2015. DOI: 10.2112 / SI73-050.1

[13] J. J. Vargas, G. Olivar, and E. Cepeda-Cuervo, "Malmquist Histórico y de Pronóstico con Series de Tiempo como Modelo Temporal de Análisis Envolvente de Datos," Inf. Tecnol., vol. 27, no. 3, pp. 141150, 2016. DOI:10.4067/S0718-07642016000300013

[14] Ministerio de Educación Nacional, "Sistema Nacional de información de la Educación Superior- SNIES, Documento metodológico,” 2019.

[15] A. F. M. Rodríguez, L. E. B. Prieto, and H. L. F. Vásquez, "Documento Metodológico MIDE Universitario 2018," p. 49, 2018.

[16] M. Sadidi, O. Khalilifar, M. Amiri, and R. Moradi, "Use of Partial Least Squares - Structural Equation Modeling for Identifying the Most Important Variables via Application of Data Envelopment Analysis," J. Arch. Mil. Med., vol. 6, no. 1, 2018. DOI: 10.5812 / jamm.67114

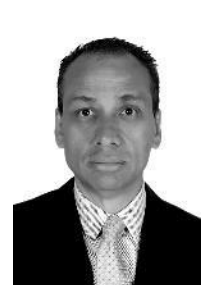

Wilson Arenas-Valencia Industrial Engineer from the Technological University of Pereira (1993), Specialist in Human Development Administration (1999), Master in Operational Research and Statistics (2005), PhD Candidate in Projects from the International IberoAmerican University.

$\mathrm{He}$ is Professor of the Industrial Engineering program at Universidad Tecnológica de Pereira since 2000. He has been dean of the Faculty of Business Sciences from 2005 to date.

ORCID: https://orcid.org/0000-0002-1485-4651

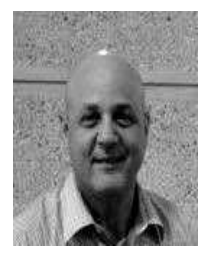

Juan José Cabello-Eras, Engineer in Automotive Transportation (U. de Cienfuegos, 1987), Magister in Mechanical Design (U. Central Marta Abreu de las Villas, 2005) and Doctor in Technical Sciences (U. Central Marta Abreu de las Villas, 2009).

Director of the Center for Energy and Environment Studies from 2009 to 2015. Director of the Department of Energy at Universidad de la Costa since 2015

ORCID: https://orcid.org/0000-0003-0949-0862 